\section{Estimation of desflurane concentration using isoflurane channel in optical infrared analyzer}

Ban C.H.Tsui MSC MD, Donald T. Jolly MD FRCP, Alexander S. Clanachan $\mathrm{PhD}^{*}$

Purpose: To estimate desflurane concentration on the isoflurane channel in an optical infrared analyzer using a simple regression equation.

Methods: Desflurane in concentrations of $0 \%$ to $3 \%$ in $0.5 \%$ increments and $3 \%$ to $12 \%$ in $1 \%$ increments in $2 \mathrm{~L} \cdot \mathrm{min}^{-1}$ oxygen was delivered simultaneously to an Ohmeda $5250 \mathrm{RGM}$ desflurane channel, an Ohmeda 5250 RGM isoflurane channel, and a Datex Capnomac Ultima isoflurane channel at room temperature and atmospheric pressure. For each concentration increment, the displayed gas concentrations were recorded. By comparing the readings from the desflurane channel of Ohmeda RGM and the isoflurane channels from Ohmeda RGM and Datex Capnomac Ultima respectively, the linear regression relationship and the slope of the fitted line (conversion factor) between two channels were obtained. Similar measurements were performed using $2 \mathrm{~L} \cdot \mathrm{min}^{-1} \mathrm{mix}-$ ture of nitrous oxide $50 \%$ and oxygen $50 \%$. The measurements were repeated with different monitors three months later.

Results: All four analysers tested were linear $\left(r^{2}>0.9\right)$ for measuring desflurane using isoflurane channels over the range of concentrations studied on two different days. The accuracy of the estimation using the mean conversion factor of the four monitors was within $10 \%$ error from the readings of the commercially available desflurane channel analyzer. There was no noticeable effect on the slope (conversion factor) of the linear regression with $\mathrm{O}_{2} 100 \%$ or $50 / 50$ mixture of $\mathrm{N}_{2} \mathrm{O}$ and $\mathrm{O}_{2}$.

Conclusion: The concentration of desflurane can be estimated by a simple conversion factor using an isoflurane channel of an infrared system.

Objectif : Estimer la concentration de desflurane sur le canal d'isoflurane d'un analyseur optique à infrarouge, en utilisant une équation à régression simple.

Méthode : Des concentrations de desflurane de $0 \%$ à $3 \%$, par accroissements de $0,5 \%$, et de $3 \%$ à $12 \%$, avec accroissements de $1 \%$, dans de l'oxygène à $2 \mathrm{~L} \cdot \mathrm{min}^{-1}$ ont été livrés simultanément à un canal de desflurane Ohmeda 5250 RGM, à un canal d'isoflurane Ohmeda 525 RGM et à un canal d'isoflurane Datex Capnomac Ultima, à la température et la pression ambiantes. Les concentrations de gaz affichées ont été enregistrées pour chaque accroissement de concentration. En comparant les relevés obtenus du canal de desflurane de Ohmeda RGM et des canaux isoflurane de Ohmeda RGM et de Datex Capnomac Ultma respectivement, la relation de régression linéaire et la pente de la ligne de régression (facteur de conversion) entre deux canaux $\mathrm{i}$ ont été obtenues. On a réalisé des mesures semblables en utilisant le mélange à $2 \mathrm{~L} \cdot \mathrm{min}^{-1}$ de protoxyde d'azote et d'oxygène à $50 \%$. Trois mois plus tard, les mesures ont été reprises avec différents moniteurs.

Résultats : Les quatre analyseurs évalués ont produit des mesures linéaires $\left(r^{2}>0,9\right)$ du desfurane en utilisant les canaux d'isoflurane selon les concentrations étudiées à deux jours différents. L'exactitude de l'estimation, qui utilisait le facteur moyen de conversion des quatre moniteurs, se situait à l'intérieur d'une marge d'erreur de 10 $\%$ des relevés produits par l'analyseur du canal de desflurane offert dans le commerce. II n'y avait pas d'effet notable sur la pente (facteur de conversion) de la régression linéaire avec $100 \%$ d'O $\mathrm{O}_{2}$ ou un mélange de $\mathrm{N}_{2} \mathrm{O}$ et d'O $\mathrm{O}_{2}$ à $50 \%$.

Conclusion : La concentration de desflurane peut être estimée par un facteur simple de conversion en utilisant un canal d'isoflurane d'un système à infrarouge.

From the Department of Anesthesia and the Department of Pharmacology, ${ }^{*}$ University of Alberta Hospitals, 3B2.32 Walter Mackenzie Health Sciences Centre, 8440-112 Street, Edmonton, Alberta, Canada T6G $2 B 7$.

Address correspondence to: Dr. Ban C.H. Tsui, Phone: 403-492-8861; Fax: 403-492-9610.

Accepted for publication November 29,1998 
A NESTHETIC agent concentration has been measured routinely in clinical practice for many years. Desflurane, a new volatile anesthetic, has gained popularity because it offers clinical advantages over isoflurane with rapid emergence and recovery of cognitive functions. ${ }^{1}$ However, many older analysers are not equipped to measure the concentration of desflurane. Commonly used analyzing systems including mass spectrometry, Raman light scattering gas and infrared analysis, are configured to detect and measure specific anesthetic gases. Selecting incorrect agent analysis channels or unrecognized gases entering these systems cause erroneous readings. ${ }^{2,3}$ The method described here estimates the concentration of desflurane by using the isoflurane channel on an optical infrared analyzer and a conversion factor based upon simple linear regression.

\section{Methods}

Using an Ohmeda Tec 6 (Ohmeda, Madison, WI, USA) desflurane vaporizer, desflurane (Suprane, Zeneca- Pharma, Mississauga, Ontario) was introduced into a circle anesthetic circuit. Concentrations of $0 \% \mathrm{v} / \mathrm{v}$ to $3 \% \mathrm{v} / \mathrm{v}$ in $0.5 \% \mathrm{v} / \mathrm{v}$ increments and $3 \%$ $\mathrm{v} / \mathrm{v}$ to $12 \% \mathrm{v} / \mathrm{v}$ in $1 \% \mathrm{v} / \mathrm{v}$ increments in $2 \mathrm{~L} \cdot \mathrm{min}^{-1}$ oxygen were delivered simultaneously to an Ohmeda 5250 RGM desflurane channel, an Ohmeda RGM 5250 isoflurane channel, and a Datex Capnomac Ultima isoflurane channel at room temperature (20C) and ambient pressure (approximately $710 \mathrm{mmHg}$ ). For each concentration increment, the displayed gas concentrations were recorded after five minutes. This permitted equilibration of the agent concentration within the circle system. By comparing the readings from the desflurane channel of the Ohmeda RGM and the isoflurane channels from the Ohmeda RGM and Datex Capnomac Ultima respectively, a linear regression relationship and the slope of fitted line (conversion factor) between the two channels were obtained. Similar measurements were performed using the 2 $\mathrm{L} \cdot \mathrm{min}^{-1}$ mixture of nitrous oxide $\mathbf{5 0 \%}$ and oxygen $50 \%$. The measurements were repeated using the same model but different monitors three months later.

\section{Results}

All four analysers were linear $\left(r^{2}>0.99\right)$ for measuring desflurane using isoflurane channels over the range of concentrations studied in two different days. The slopes of each regression for each analyzer are summarized in the Table. The mean of conversion factors ( $1 /$ slope) of each linear regression for two Ohmeda RGM 5250 and two Datex Capnomac Ultima tested with oxygen 100\% and a mixture of nitrous oxide $50 \%$ and oxygen $50 \%$ at $2 \mathrm{~L} \cdot \mathrm{min}^{-1}$ was 0.72 . Using ANOVA, the calibration slopes obtained from each analyzer were different from each other $(P<0.01)$. The percent error of the estimated desflurane concentration from isoflurane readings using the mean conversion factor against known concentrations of $0-12 \% \mathrm{v} / \mathrm{v}$ desflurane with oxygen $100 \%$ and $50 / 50$ mixture of nitrous oxide and oxygen at $2 \mathrm{~L} \cdot \mathrm{min}^{-1}$ is shown in Figure 2. The accuracy of each actual estimation of desflurane concentration was with-

TABLE Conversion factors for each analyzer

\begin{tabular}{|c|c|c|c|c|c|}
\hline Legend & machine or condition & slope & $\begin{array}{l}\text { standard } \\
\text { diviation }\end{array}$ & $r^{2}$ & $\begin{array}{l}\text { conversion factor } \\
(1 / \text { slope })\end{array}$ \\
\hline $\mathrm{RGMl}-\mathrm{O}_{2}$ & $\begin{array}{l}\text { \# } 1 \text { Ohmeda RGM } 5250 \\
\left(100 \% \mathrm{O}_{2}\right)\end{array}$ & 1.399 & 0.053 & 0.995 & 0.715 \\
\hline $\mathrm{RGMl}-\mathrm{N}_{2} \mathrm{O}$ & $\begin{array}{l}\text { \# } 1 \text { Ohmeda RGM } 5250 \\
\left(50 / 50 \text { mixture } \mathrm{N}_{2} \mathrm{O} / \mathrm{O}_{2}\right)\end{array}$ & 1.400 & 0.025 & 0.999 & 0.714 \\
\hline $\mathrm{RGM} 2-\mathrm{O}_{2}$ & $\begin{array}{l}\# 2 \text { Ohmeda RGM } 5250 \\
\left(100 \% \mathrm{O}_{2}\right)\end{array}$ & 1.349 & 0.052 & 0.996 & 0.741 \\
\hline $\mathrm{RGM} 2 \cdot \mathrm{N}_{2} \mathrm{O}$ & $\begin{array}{l}\text { \# } 2 \text { Ohmeda RGM } 5250 \\
\left(50 / 50 \text { mixture } \mathrm{N}_{2} \mathrm{O} / \mathrm{O}_{2}\right)\end{array}$ & 1.382 & 0.019 & 0.999 & 0.723 \\
\hline $\mathrm{DATl}-\mathrm{O}_{2}$ & $\begin{array}{l}\text { \# } 1 \text { Datex Capnomac Ultima } \\
\text { Ultima }\left(100 \% \mathrm{O}_{2}\right)\end{array}$ & 1.450 & 0.041 & 0.997 & 0.689 \\
\hline DATl- $\mathrm{N}_{2} \mathrm{O}$ & $\begin{array}{l}\text { \# } 1 \text { Datex Capnomac } \\
\text { Ultima }(50 / 50 \text { mixture } \\
\left.\mathrm{N}_{2} \mathrm{O} / \mathrm{O}_{2}\right)\end{array}$ & 1.414 & 0.028 & 0.998 & 0.707 \\
\hline DAT $2 \cdot \mathrm{O}_{2}$ & $\begin{array}{l}\text { \#2 Datex Capnomac } \\
\text { Ultima }\left(100 \% \mathrm{O}_{2}\right)\end{array}$ & 1.307 & 0.021 & 0.999 & 0.765 \\
\hline DAT2- $\mathrm{N}_{2} \mathrm{O}$ & $\begin{array}{l}\text { \# } 2 \text { Datex Capnomac } \\
\text { Ultima }(50 / 50 \text { mixture } \\
\left.\mathrm{N}_{2} \mathrm{O} / \mathrm{O}_{2}\right) \\
\text { Average }\end{array}$ & 1.336 & 0.018 & 0.999 & 0.748 \\
\hline
\end{tabular}


in $\pm 0.5 \% \mathrm{v} / \mathrm{v}$ over the range of $0.5 \% \mathrm{v} / \mathrm{v}$ to $12 \% \mathrm{v} / \mathrm{v}$ desflurane concentration.

\section{Discussion}

Since the majority of anesthetic agents exhibit strong absorption near $3.1 \mu \mathrm{m},{ }^{3-7}$ many clinical infrared analyzers operate near this wavelength. The operation of Ohmeda RGM 5250 and Datex Capnomac Ultima analyzers is based on infrared absorption at $3.3 \mu \mathrm{m} .{ }^{4}$ Both measure the spectrum of anesthetic gas between $3.24 \mu \mathrm{m}$ and $3.39 \mu \mathrm{m} .{ }^{4}$ Within this range, the absorption spectra of desflurane and isoflurane are similar and both peak at approximately $3.27 \mu \mathrm{m}$ and 3.32 $\mu \mathrm{m}$. The relative absorption peak heights of desflurane to isoflurane are approximately 0.81 and 0.8 at 3.27 $\mu \mathrm{m}$ and $3.32 \mu \mathrm{m}$, respectively. ${ }^{4}$ Thus, the concentration of desflurane might be estimated by the use of a simple conversion factor using the isoflurane channel.

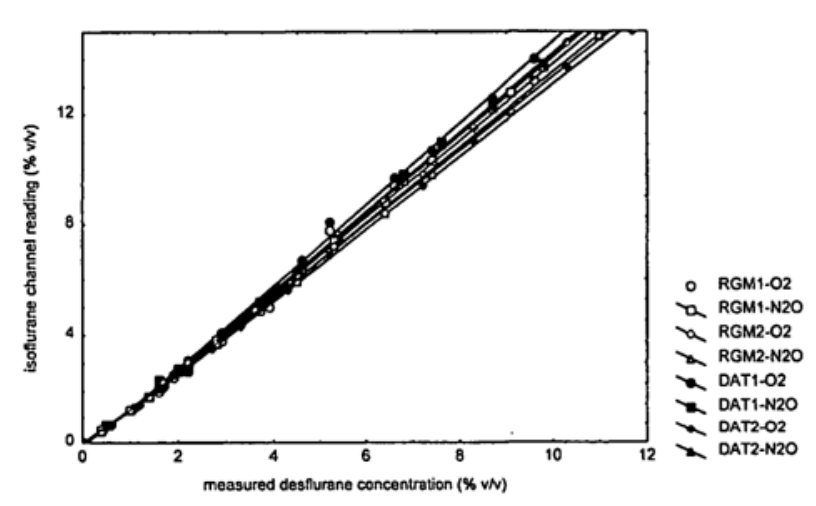

FIGURE I Relationship between readings from desflurane channel and isoflurane channel

Legend: see Table for identification of each analyzer

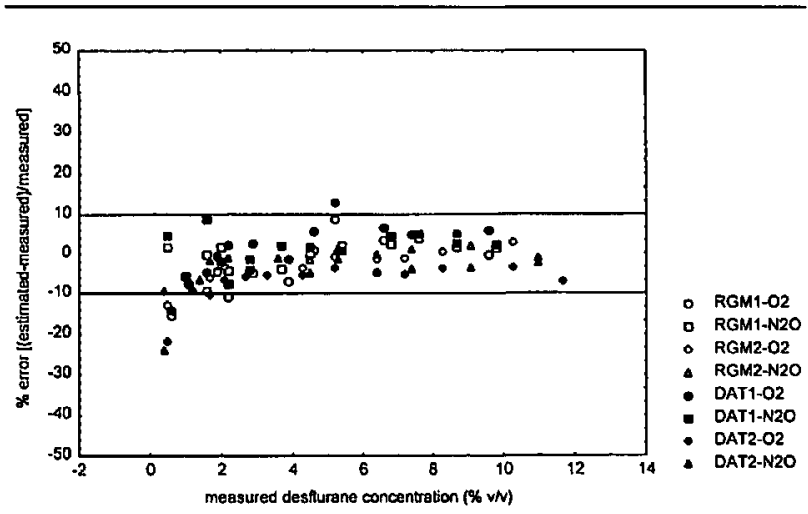

FIGURE 2 Percent error of the estimated desflurane concentration from isoflurane readings using the mean conversion factor. Legend: see Table for identification of each analyzer.
Infrared analyzers should be tested and calibrated according to the manufacturer's service schedule using a standard halogenated gas mixture. At our institution, infrared analyzers undergo testing and calibration every six months. We did not calibrate each analyzer on a day-to-day basis. Randomly available analyzers were selected without additional calibration prior to the study to reflect usual clinical practice. We performed the estimation using two commonly used gas mixtures $\left(\mathrm{O}_{2}, 100 \%\right.$ and $50 / 50$ mixture of $\mathrm{N}_{2} \mathrm{O} / \mathrm{O}_{2}$ ). There was no effect on the slope (conversion factor) of the linear regression under $\mathrm{O}_{2} 100 \%$ or $50 / 50$ mixture of $\mathrm{N}_{2} \mathrm{O} / \mathrm{O}_{2}$ (Table, Figure 1) suggesting that $\mathrm{N}_{2} \mathrm{O}$ did not affect the accuracy of estimation.

When desflurane was sampled by infrared systems using isoflurane channels, there was a linear relationship between the isoflurane readings and the actual desflurane concentration measured by the desflurane channel. The actual measured desflurane level was approximately 0.72 times the isoflurane reading from the isoflurane channel. Despite the similarity of the estimated slopes for each analyzer (Figure 1, Table), the calibration slopes obtained from each analyzer were different from each other $(P<0.01)$. This difference was likely due to an extremely tight fitted regression $\left(\mathrm{r}^{2}>0.99\right)$ and small standard deviation of each slope for each analyzer. However, the percent error of the estimated desflurane concentration from isoflurane readings using the mean conversion factor was within approximately $\pm 10 \%$ from the readings obtained with the commercially available desflurane channel analyzer (Ohmeda RGM 5250) over the range of $1-12 \%$ desflurane (Figure 2). The accuracy of each estimation of desflurane concentration was within $\pm 0.5 \%$ over the range of $0.5-12 \%$ desflurane. These estimations would be acceptably accurate for clinical purposes. Thus, the difference between the estimation slopes of each analyzer may not be clinically relevant.

These findings require cautious interpretation. Since only four machines were tested, the conversion factor presented is intended only as a guideline. Individual monitors may require separate evaluation. Potential errors may arise from temperature and barometric pressure changes as well as in anesthetic circuit flow rates which were not assessed. Confirmation of the conversion factor under specific physical conditions needs to be performed prior to clinical use. The conversion factor accuracy has only been evaluated in vitro without the influence of ventilation and of the presence of $\mathrm{CO}_{2}$. Another, potential problem of using the isoflurane channel to estimate desflurane is the risk of disabling or adjusting the isoflurane alarm limit to its highest setting. 
In conclusion, the concentration of desflurane can be estimated by a simple conversion factor when using an isoflurane channel of an infrared system such as the Datex Capnomac Ultima and the Ohmeda RGM 5250 with comparable readings from the commercial product Ohmeda RGM 5250 desflurane channel.

\section{Acknowledgment}

The authors thank Mr. Taras Sembaliuk, Department of Biomedical Engineering, University of Alberta Hospital, for his contribution.

\section{References}

1 Ghouri AF, Bodner M, White PF. Recovery Profile after desflurane-nitrous oxide versus isoflurane-nitrous oxide in outpatients. Anesthesiology 1991; 74: 419-24.

2 Abel M, Eisenkraft JB. Erroneous mass spectrometer readings caused by desflurane and sevoflurane. J Clin Monit 1995; 11: 152-8.

3 Dorsch JA, Dorsch SE. Understanding Anesthesia Equipment, 3rd ed. Baltimore: Williams and Wilkins, 1994: 547.

4 Datex Capnomac Ultima ${ }^{\mathrm{TM}}$ Service Manual, DatexOmeda, Inc., Tewksbury, MA, USA November 1st, 1993/4.

5 Raemer DB, Pbilip JH. Monitoring anesthetic and respiratory gases. In: Blitt $\mathrm{CD}$ (Ed.). Monitoring in Anesthesia and Critical Care Medicine, 2nd ed. New York: Churchill Livergstone Inc., 1990: 373-86.

6 Brient SE, van der Aa J, Gravenstein JS, Sosis MB. Respiratory gas monitors. In: Sosis MB (Ed.). Anesthesia Equipment Manual, Philadelphia: Lippincott-Raven Publishers, 1997: 157-69.

7 McPeak H, Palayiwa E, Madgwick R, Sykes MK. Evaluation of a multigas anesthetic monitor: the Datex Capnomac. Anaesthesia 1988: 43: 1035-41. 